\title{
A.JO'「E
}

African Journal of Teacher Education

ISSN 1916-7822. A Journal of Spread Corporation

Volume $92020 \quad$ Pages $80-103$

\section{Process skills application and scientific attitudes of Biology students in colleges of education in southwestern Nigeria}

\author{
Adeyinka Oluwaseun Kareem, Moruf Ademola Adeleke, \\ \& Marie Onovroghene Salami \\ Department of Science and Technology Education \\ Obafemi Awolowo University, Ile-Ife, Nigeria
}

\begin{abstract}
West African Examination Council results have continued to reveal Nigeria's high school students' poor performance in Science subjects, and especially, in practical science (WAEC 2014). The students' demonstration of essential scientific attitudes is noted to be deficient. This is possibly caused by ineffective teaching and learning produced by the absence of necessary practical classes. This study, therefore, assessed the process skills application and scientific attitudes of Biology students in colleges of education in southwestern Nigeria as well as the relationship between the two variables. These groups of variables are central to students developing skills and knowledge in science and a determination of levels of competence in them would facilitate appropriate interventions to improve teaching and learning of science. The study adopted descriptive research survey design. The population for the study included all Biology students in colleges of education in southwestern Nigeria. From the four federal and seven state colleges of education in southwestern Nigeria, two federal colleges of education and three state colleges of education were randomly selected to ensure adequate representation of the two school categories. One hundred Biology students were randomly selected from each of the two school categories. Two instruments were used for the study. These were Biology Process Skill Application Rating Scale (BPSARS) and Biology Scientific Attitude Questionnaire (BSAQ). A reliability value of 0.72 for BPSARS and 0.76 for BSAQ was gotten using Cronbach alpha coefficient. The result revealed that there existed a moderate application of process skills and a moderate level of scientific attitude among the respondents as $67.3 \%$ and $84.8 \%$ having a moderate level of process skills application and
\end{abstract}


Process skills application and scientific attitudes of Biology students in colleges of education in southwestern Nigeria.

scientific attitude respectively. It was shown that there was no significant relationship between the process skill application and scientific attitude $(r=0.09, p>0.05)$ of respondents in the study area.

Keywords: Process Skills Application, Scientific Attitude, colleges of education

\section{Introduction}

An important goal of Science Education enshrined in Nigeria's National Policy on Education (FRN, 2014) is the emphasis on the teaching and learning of science processes and principles for individual and national development by providing knowledge and understanding of the complexity of the world and human environment at large. The Federal Government of Nigeria emphasized the importance of all-round education to assist learners in acquiring appropriate skills, competencies and abilities so that they can live and commit to the development of the society (FRN, 2014). Arokoyu and Nna (2012) believed that knowledge and skills which we have known as the core components of science education are essential factors for scientific creativity and developments.

The literature highlights three important dimensions of science teaching. This is the content or the basic concepts that embed scientific knowledge. This is the aspect of science that most people first think about, and it is certainly very important. The other two important dimensions of science teaching are the processes of engaging in science and scientific attitudes. The processes of carrying out scientific investigations and activities are the science process skills that scientists use during experiment (Lloyd and Kathleen 2012; Omoifo (2012). These are the skills that are used generally in daily lives as people try to find answers to everyday questions. This means that as students are taught science process skills, they are also taught how to live both in the present and in subsequent situations. These skills are applicable to every human activities and endeavors. The third dimension of science focuses on dispositions and characteristic attitudes to science. Of science contents, processes and attitudes, three interrelated aspects of science, Omoifo (2012) noted that contents are the concepts in various fields of sciences whose practical application is taught using process skills. The resultant effects of these aspects are reflected in the student's scientific attitudes. These skills are important to make students build on various attitudes that will help them become better in the society. Process skills prepare students for scientific explorations and endeavours.

Lloyd and Kathleen's (2012) notion of process skills was that ability to merge the Science Process Skills (SPS) with classroom lessons and research and experimental activities would make the learning experiences more valuable and meaningful for students. They believed that students 
would learn the of scientific skills as well as science content and would be actively engaged with the science they are learning. It is also believed that building these skills will help students understand what they need to become better scientists who display appropriate scientific attitudes. These skills are divided into Basic Process Skills and Integrated Process Skills. The basic skills are the fundamental skills students use in scientific activities. involve their use of the sense organs for observation, taking accurate measurements and grouping objects into various classes, termed classification, using words to exchange information, forming assumptions, i.e., inferences and providing rationale for predictions. Process skills also include generic ones like hypothesizing a give problem, carrying out experiments, improvising by manipulating and changing conditions for experiments as a well as interpreting data and formulating models. These generic skills require the use of two or more basic process skills.

The National Educational Research Development Council (NERDC) and National Universities Commissions (NUC) have been involved in the development of various curricula that emphasize the acquisition of SPS in use at different levels of Nigeria's education system (Babajide, 2015). Some aspects of Nigeria's secondary and tertiary education curricula include the objectives to expose and train students to successfully learn and acquire science processes skills that will empower them to overcome challenges, make decisions, and live as effective global citizens contributing to the attainment of Nigeria's national goals (Ekon \&Eni, 2015). Despite these efforts, research suggest poor development and non-acquisition of science process skills in Nigerian secondary schools because not many students are exposed to science practical activities at this level (Nwosu, 2006; Idigie, Nja and Ugwu 2017). The consequence of students not learning science the right way is a logical inability to acquire the basic attitudes of science.

But why would science teachers fail to inculcate science process skills during practical classes when teaching their students? Investigations carried out have shown that practical classes where students learn about process skills in more concrete ways are rarely taught by teachers until shortly before students sit for their final external certification examinations. Discussing why teachers are the most impediment to students developing the science process skills, Ango (2002) reported that they lack expertise, having themselves not been always well trained and guided during their training as teacher educators. This is induced by the poor state of practical laboratories as well as factors like the knowledge level of teacher trainers, their disposition towards science teaching, 
which would normally include the development of scientific attitudes as a component. The trainer and the teacher can teach their students only what they have expertise in and the level of teaching expertise they used to inculcate these skills in their students would determine how the students apply those skills. Thus, a poor level of acquisition of process skills would mean that student's interest in science would likely be poorly developed. This would similarly negatively result in poorly developed scientific attitude. Acquiring science process skills, however, forms the bedrock for inquiry in science and for the development of intellectual skills and attitudes that are prerequisites to learning of scientific concepts (Nwagbo \& Uzoamaka, 2011).

Scientific attitudes are as important as the science process skills; it is in the attitude that the true nature of the skills acquired is expressed. These attitudes include cognitive components of rationality, intellectual belief, and aversion to suspicion; emotional components of perseverance, humility, and honesty; and affective components that include curiosity, self-reliance, suspended judgment, proactiveness and open mindedness. Cheung (2009) and Utsa \& Akkant (2014) have reported a correlation between students' high positive scientific attitude and considerable improvement in academic achievement in science subjects. It also had a positive effect on scientific creativity of students. Therefore, teacher focus should not be on academic achievement in science subject alone but in the students' attitudes towards science as well. Sirhan (2007) observed that attitudes and motivation are important in aiding meaningful learning; noting that success in learning and positive attitudes to learning are linked. Gokul and Malliga (2015) believe that the science teacher serves as the major developer of scientific attitude in students as s/he manipulates all situation during the application of process skills to inculcate in pupils the requisite scientific attitude. The teacher also serves as an example to the students in demonstrating intellectual honesty, respect for others' points of view, and exhibiting an unbiased and impartial behavior.

Various empirical studies have been carried out on process skills and scientific attitudes in different areas. Segumpa's (n.d.) work on Bruneian students' science process showed the pre service teachers in all science inquiry processes had an average overall competency level, average competency level of basic skills (Mean $=17.82$; Max $=30$ ) and a poor competency level of integrated science inquiry skills. (Mean $=11.30 ;$ Max $=30)$. Segumpa's work showed the highest competency levels for observing, measuring and quantifying skills while classifying, formulating models, interpreting data and inferring rated average, and experimenting, controlling variables and 
predicting were poor. Giwa, Libata and Wakkala (2018) worked on the relationship between science process skills and student attitude toward physics in senior secondary school. The results on the process skills revealed that interpretation of data, observation and measuring were the highest skills while the overall mean score was 1.33 which is synonymous on a scale that the knowledge of process skills was poor. Sunyono (2018)'s work on science process skills characteristics of junior high school Students in Lampung, Indonesia revealed an average level of process skills by the students. It was also revealed that observation and classification skills were average, the skill of predicting, interpreting and communicating were the lowest skills of the respondents. Azizah, Ibrahim, Widodo (2018)'s work on process skill assessment instrument for use in an Indonesian school revealed that observation, measurement, classifying and communication had a high level of process skills respectively while hypothesis and Inferring were low. Their study revealed an overall high level of process skills with a mean score of 0.78 .

O. R. Olatoun (2017) investigated scientific attitude development of Chemistry graduate employees in some selected industries in southwest Nigeria. The results of the study revealed that the level of scientific attitudes developed by chemistry graduates from undergraduate chemistry courses was lower than scientific attitudes required by the industries. Ten scientific attitudes were used for the study. These were self-reliance, open mindedness, flexibility, perseverance, adaptability, proactiveness, honesty, initiative, respect and integrity. It was revealed that the respondents had a high level of scientific attitude while integrity and honesty had the highest scores. Pitafi and Farooq's (2012) study of scientific attitude of secondary school students in Pakistan utilized eight constructs of scientific attitude. These constructs included curiosity, rationality, willingness to suspend judgment, open mindedness, critical mindedness, objectivity, honesty and humility. The study revealed that the attitude of students in the study area was slightly scientific. The scientific attitudes that rated highest were curiosity and critical mindedness while the lowest scoring ones were willingness to suspend judgment and rationality. In M. P. Lacap's (2015) study of the scientific attitude of Philippines' students majoring in science, the dimensions of attitudes measured were rationality, curiosity, open mindedness, aversion to superstition, objectivity of intellectual beliefs and suspended judgment. Open-mindedness had the highest mean of 3.88 which was rated high. This means that the students were very much willing to learn new things and ideas. It was also revealed that the students had a high rate of aversion to superstition, curiosity and 
Process skills application and scientific attitudes of Biology students in colleges of education in southwestern Nigeria.

objectivity of intellectual belief while a moderate level of scientific knowledge for rationality and suspended judgment.

Scientific attitudes are to be developed during hands on activities that promote and encourage students to carry out tasks by themselves and these can only be carried out via the application of process skills. How much of these are been done in teacher education colleges in Nigeria is not clear. Hence, ascertain how much of scientific attitude the teachers possess is equally largely unclear. An assessment of these skills and attitude in teachers who will teach the students in secondary schools thus remains an important task to be carried out so that remediation can be made where necessary for both the present and future pre service teachers. Our goal for the current study was to fill this gap.

\section{Statement of Problem}

The essence of scientific teaching and learning is to inculcate specific scientific skills and attitudes in the students. These skills and attitudes are pre requisites for the mental training and development of the students. Students will be able to apply the skills and attitudes they cultivate to everyday life and these will help them generate ideas that contribute value to the society in the best possible way. The West African Examination Council has consistently complained about the poor performance of students in Science subjects, and especially in practical science. Danmole (2012) has noted that teachers in Nigeria seem to believe that Biology can be taught effectively without practical. This reveals a gap in the understanding of the necessity of process skill application in learning science. Nigeria's science students have consequently not been able to demonstrate essential scientific attitudes. The need to assess the process skill application and scientific attitude of Biology students in colleges of education in colleges of education in southwestern Nigeria in order to be able to apply appropriate policy intervention has the be reason for this study.

\section{Significance of the Study}

An essential component teaching science is ensuring that students inculcate various requisite science skills, processes, and attitudes all of which are required not only for effective professional life but also for effectual contribution to nation building. Biology is one of the important science subjects taught in Nigerian schools that can offer these qualities to students. The study will thus provide education planners and the teachers in Nigeria's colleges of education information on how well students apply process skills as well as indicate to them areas where students need help in 
acquiring and applying process skills. It will also provide information on the level of scientific attitudes of Biology students in colleges of education in Southwestern Nigeria and what specific variables need to be worked on.

\section{Objectives of Study}

1. determine the level of Process Skill Application (PSA) of Biology students in Colleges of Education in Southwestern Nigeria;

2. examine the Scientific Attitudes (SA) of Biology students in Colleges of Education in the study area

3. examine the relationship between process skills application and scientific attitude of Biology students in Colleges of education in southwestern Nigeria.

\section{Research Question}

1. What is the level of application of process skills of Biology students in Colleges of Education in the study area?

2. How adequate are the scientific attitudes of Biology students in Colleges of Education in the study area?

\section{Research hypothesis}

There is no significant relationship between process skills application and scientific attitudes of Biology students in colleges of education in Southwestern Nigeria

\section{Methodology}

The study adopted descriptive survey research design. The population for the study comprised of all Biology students in colleges of education in Southwestern Nigeria. The study sample size comprised of 500 Part III Biology students from five colleges of education in the study area. Using simple random sampling technique, two federal colleges of education (Ondo and Oyo) were selected out of the four federal colleges of education in four of the six southwestern Nigeria states (Oyo State, Ogun State, Lagos State, Ondo State). Simple random sampling technique was also used to select three state colleges of education from the seven existing in Southwestern Nigeria. These were the state colleges of education in Oyo, Osun and Ekiti states. This was done to ensure 
adequate representation of the two school categories. Using simple random sampling technique, fifty students from each of Biology/Chemistry and Biology/Integrated Science combinations were selected to make a total of 100 National Certificate in Education (NCE) Biology students in each of the selected colleges of education.

Two research instruments were used for this study, namely: Biology Process Skills Application Rating Scale (BPSARS) and Biology Scientific Attitude Questionnaire (BSAQ). BPSARS was used to rate the process skills application competence of the students while BSAQ provided information on their scientific attitude. The instruments were validated by content and exploratory factorial analysis. The reliability test for each instrument was also determined. BPSARS yielded a reliability coefficient of 0.72 and 0.89 using Cronbach alpha and Guttman split half coefficient respectively. BSAQ yielded a reliability coefficient of 0.760 and 0.672 using Cronbach alpha and split-half coefficient respectively. Data collected was analyzed using appropriate descriptive and inferential statistics. The analysis included descriptive statistics of frequency and percentages, mean, standard deviation, skewness and inferential statistics of multivariate analysis of variance, bivariate Pearson product moment correlation.

Results

\section{Research Question One}

- What is the level of application of process skills of Biology students in Colleges of Education in the study area?

To answer this research question, data were collected for each of the components of the process skills application. Components that had more than one description, with elements that included observation, measurement, prediction, hypothesis, experimenting, and interpreting data, were summed up to give a total process skill score for each item. The various skills were then grouped into the two basic categories of process skills, i.e., Basic Process Skill and Integrated Process Skill. This was done by adding the various scores of the items together. For the basic process skills, scores for observation, measurements, classification, communicating, inferencing, prediction were added together and for the integrated process skills, scores for hypothesizing, experimenting, manipulative skills, controlling variables, interpreting data and formulating models were added together. All the scores were then added together to give a total score for process skills application. The students were observed and their marked practical manuals were checked to make 
two sets of observations. The responses in the practical manuals were compared with the instructions specified in the manuals and the specimens/ equipment that were supplied for the respective practical. This was also done to assess the components which were not observed during real-time practical. The average (to the nearest whole number) of the scores for the two observations were taken as the final score. The result is presented in Table 1

Table 1: Descriptive Analysis of Process Skills of the Biology Students in Colleges of Education in Southwestern Nigeria

\begin{tabular}{|c|c|c|c|c|c|c|c|c|c|}
\hline$\overline{\text { Skills }}$ & Min. & Max. & Mean. & $\begin{array}{l}\text { Stand. } \\
\text { Dev. }\end{array}$ & $\begin{array}{l}\text { Stand. } \\
\text { Error }\end{array}$ & $\begin{array}{l}\text { Adjusted } \\
\text { Mean }\end{array}$ & Rank & Skewness & $\begin{array}{r}\text { Std. Error } \\
\text { of } \\
\text { Skewness }\end{array}$ \\
\hline Observation & 1.00 & 14.00 & 9.12 & 2.85 & 0.23 & 60.80 & 2 & -0.65 & 0.20 \\
\hline Measurement & 0.00 & 15.00 & 7.64 & 3.40 & 0.28 & 50.93 & 6 & 0.25 & 0.20 \\
\hline Classification & 0.00 & 4.00 & 2.15 & 3.52 & 0.29 & 43.00 & 9 & 0.10 & 0.20 \\
\hline Communicating & 0.00 & 5.00 & 3.13 & 1.32 & 0.11 & 62.60 & 1 & -0.09 & 0.20 \\
\hline Inferencing & 0.00 & 5.00 & 2.80 & 1.15 & 0.09 & 43.60 & 8 & -0.13 & 0.20 \\
\hline Predicting & 0.00 & 9.00 & 4.22 & 2.31 & 0.19 & 42.20 & 10 & 0.31 & 0.20 \\
\hline Hypothesizing & 1.00 & 10.00 & 4.44 & 2.03 & 0.17 & 44.40 & 7 & 0.49 & 0.20 \\
\hline Experimenting & 2.00 & 10.00 & 5.33 & 2.47 & 0.20 & 53.30 & 5 & 0.25 & 0.20 \\
\hline Manipulating & 0.00 & 5.00 & 2.98 & 1.49 & 0.12 & 59.6 & 3 & 0.05 & 0.20 \\
\hline $\begin{array}{l}\text { Controlling } \\
\qquad \text { Variable }\end{array}$ & 0.00 & 5.00 & 2.74 & 1.47 & 0.12 & 54.8 & 4 & 0.36 & 0.20 \\
\hline Interpreting Data & 0.00 & 8.00 & 3.89 & 1.72 & 0.14 & 38.9 & 11 & 0.13 & 0.20 \\
\hline $\begin{array}{l}\text { Formulating } \\
\text { Model }\end{array}$ & 0.00 & 5.00 & 1.29 & 0.84 & 0.07 & 25.8 & 12 & 1.42 & 0.20 \\
\hline
\end{tabular}

Adjusted Mean $=\underline{(\text { mean of classified SPS x }(\text { Total max. Score obtainable from TSPS })}$

Max. Score obtainable in items of classified SPS

Table 1 reveal the mean and adjusted mean values for each of the process skills. This was to determine the most applied process skills among the respondents. It is clear from the table that 

southwestern Nigeria.

communicating skill was the most applied skill by the respondents as it ranks 1 with adjusted mean value of 62.60 . This is followed by observation and manipulative skills respectively with the adjusted mean value $\left({ }^{\bar{x}}\right)$ of 60.80 and 59.60 respectively. This is followed by controlling variable, experimenting, measurement, hypothesis, inferencing, classification, predicting, interpreting data and formulating models which were ranked from 4 to 12 with adjusted mean scores of 54.8, 53.30, $50.93,44.40,43.60,43.00,42.00,38.9,25.8$.

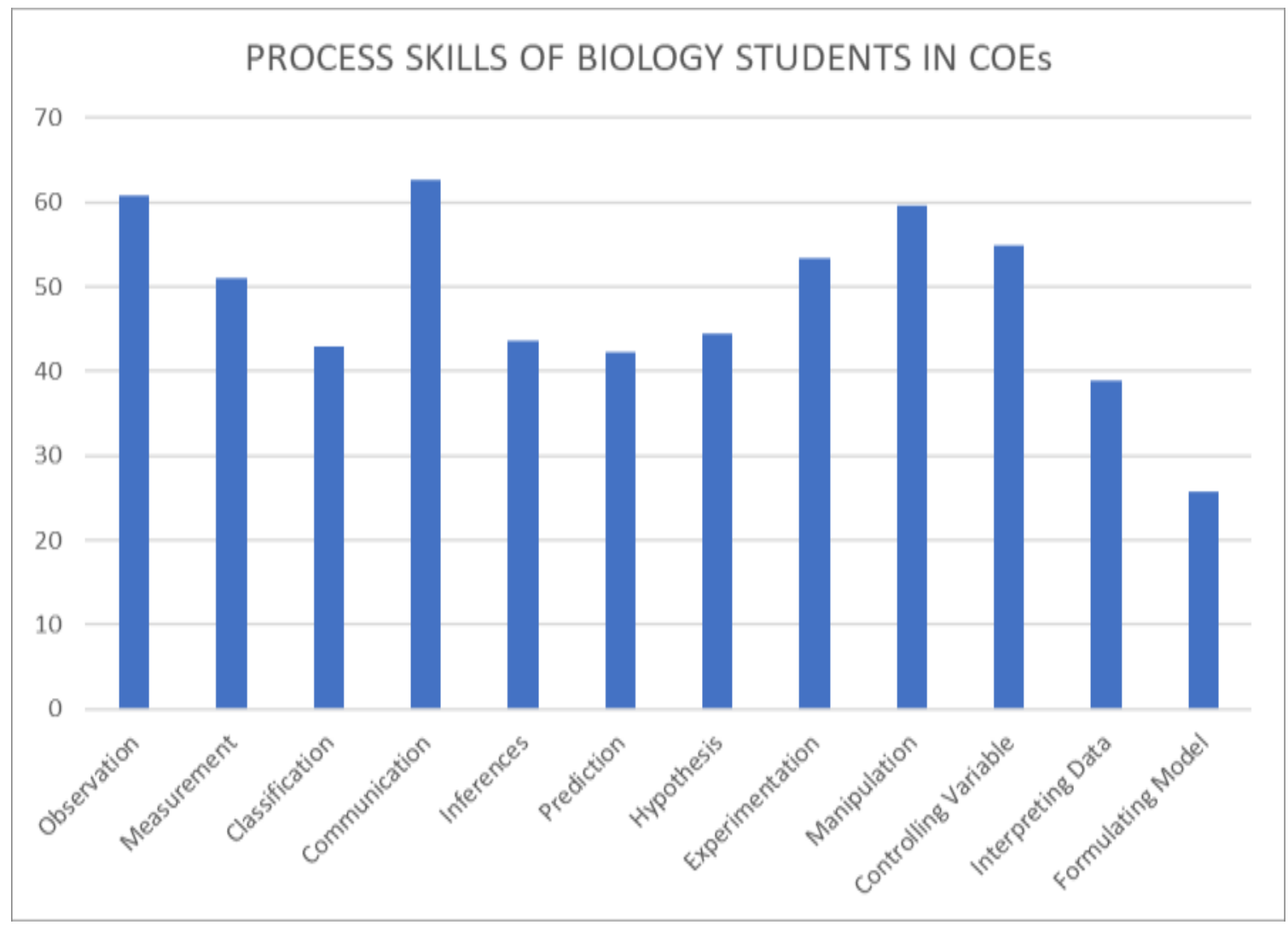

Figure 1. Bar Graph of Process Skills Application of Respondents in Colleges of Education in Southwestern Nigeria

Table 2. Descriptive Analysis of the Components of Process Skill Application 
Skill Max. Min. Max. Mean. Stand. Adjusted Rank Skewness Std. Error Score Dev. Mean

\begin{tabular}{llllllllll}
\hline Basic PSA & 55 & 10.00 & 48.00 & 29.84 & 9.17 & 54.25 & 1 & -0.005 & 0.198 \\
Integrated PSA & 45 & 5.00 & 40.00 & 20.74 & 7.81 & 46.09 & 2 & 0.025 & 0.198 \\
Total PSA & 100 & 19.00 & 83.00 & 50.65 & 15.44 & & & 0.074 & 0.198 \\
\hline
\end{tabular}

Adjusted Mean $=\underline{\text { (mean of classified PSA } x(\text { Total max. Score obtainable from TPSA })}$

Max. Score obtainable in items of classified PSA

Table 2. compared the levels of process skill application by respondents in the study area and observed that the level of utilization was higher for basic or generic process skills than for the integrated process skill; this is confirmed in the adjusted mean score of the two categories. The adjusted mean was used because the number of items in each category was not equal. This was then calculated to achieve uniformity in the mean of the categories. Comparing the mean score to the maximum obtainable scores (MBPSA $=55$, MIPSA $=45$ ), it can be educed that there was a moderate (average) level of basic and integrated process skill application as well as a moderate level of the general application of process skills among the respondents.

The process skills were categorized into low, moderate, and high level and the results are presented in the table below.

Table 3: Level of Process Skills Application of Respondents in Colleges of Education in Southwestern Nigeria.

\begin{tabular}{lllll}
\hline Skills & Frequency & Percentage (\%) & Decision \\
\hline \multicolumn{2}{l}{ Basic Process Skills } & & & \\
\multicolumn{2}{l}{ Loderate } & 20 & 13.3 & Moderate \\
& & 91 & 60.7 &
\end{tabular}


Integrated Process Skills

Low

40

26.7

Moderate

Moderate

High

20

Total Process Skills

Low

20

13.3

Moderate

Table 3. shows the level of basic process skills exhibited by the respondents. The majority (60.7\%) demonstrated a moderate level of basic process skills application, while $26.0 \%$ of the respondents demonstrated a high level of basic process skills application. Only 13.3\% demonstrated a low level of basic process skills.

The result in Table 3 also shows the level of integrated process skills demonstrated by the respondents. $60.0 \%$ of the respondents demonstrated a moderate level of integrated process skills, $26.7 \%$ of the respondents demonstrated a low level of integrated process skills, while $13.3 \%$ demonstrated a high level of integrated process skills. The table also reveals the overall level of process skills application exhibited by the respondents. Most of the respondents (67.3\%) demonstrated a moderate level of basic process skills, while 19.3\% demonstrated a high level of process skills application, and $13.3 \%$ demonstrated a low level of process skills application.

It could be concluded that there was a moderate level of application of basic process skills and integrated process skills application among the respondents as there was a moderate level of application of overall process skills among the respondents.

\section{Research Question Two:}

- How adequate is the scientific attitude of respondents in the study area?

The items under each component of behavior were added together to get a single score for each of the components. Since the number of items was different, adjusted mean was used to get a unified mean so that the mean score for all the components could be determined and compared 
Table 4: Descriptive Analysis of Scientific Attitude of the Biology Students in Colleges of Education in Southwestern Nigeria

\begin{tabular}{|c|c|c|c|c|c|c|c|c|}
\hline \multirow[t]{2}{*}{ Scientific Attitude } & \multirow[t]{2}{*}{ Min. } & \multirow[t]{2}{*}{ Max. } & \multirow[t]{2}{*}{ Mean. } & \multirow{2}{*}{$\begin{array}{l}\text { Stand. } \\
\text { Dev. }\end{array}$} & \multirow{2}{*}{$\begin{array}{l}\text { Adjusted } \\
\text { Mean }\end{array}$} & \multirow[t]{2}{*}{ Rank } & \multirow[t]{2}{*}{ Skewness } & \multirow{2}{*}{$\begin{array}{l}\text { Std. Error } \\
\text { of } \\
\text { Skewness }\end{array}$} \\
\hline & & & & & & & & \\
\hline Rationality & 2.00 & 8.00 & 5.62 & 1.48 & 74.47 & 6 & -0.550 & 0.109 \\
\hline $\begin{array}{c}\text { Intellectual } \\
\text { belief }\end{array}$ & 2.00 & 8.00 & 6.25 & 1.33 & 82.81 & 3 & -0.71 & 0.109 \\
\hline $\begin{array}{l}\text { Aversion to } \\
\text { suspicion }\end{array}$ & 3.00 & 12.00 & 8.15 & 1.95 & 71.99 & 7 & -0.19 & 0.109 \\
\hline Perseverance & 3.00 & 12.00 & 9.20 & 1.79 & 81.27 & 4 & -0.38 & 0.109 \\
\hline Humility & 2.00 & 8.00 & 5.35 & 1.51 & 70.89 & 8 & -0.35 & 0.109 \\
\hline Honesty & 2.00 & 10.00 & 4.50 & 1.91 & 59.63 & 10 & -0.95 & 0.109 \\
\hline Curiosity & 2.00 & 8.00 & 6.59 & 1.25 & 87.31 & 1 & -1.15 & 0.109 \\
\hline Self-Reliance & 2.00 & 8.00 & 6.39 & 1.38 & 84.67 & 2 & -0.97 & 0.109 \\
\hline Suspended & 3.00 & 12.00 & 6.63 & 1.82 & 58.57 & 11 & -0.89 & 0.109 \\
\hline Judgment & & & & & & & & \\
\hline Proactive & 3.00 & 12.00 & 8.84 & 2.00 & 78.09 & 5 & -0.70 & 0.109 \\
\hline Openminded & 2.00 & 10.00 & 5.23 & 1.82 & 69.30 & 9 & 1.53 & 0.109 \\
\hline
\end{tabular}

Adjusted Mean $=\underline{(\text { mean of classified SA } \times(\text { Total max. Score obtainable from SA) }}$

Max. Score obtainable in items of classified SA

The result in table 4 shows the relative scientific attitude possessed by Biology students in COEs in southwestern Nigeria. It reveals curiosity scoring the highest among attitudes the students have with adjusted mean score 87.31 which was ranked 1, this was followed by self-reliance ranked 2 with an adjusted mean score of 84.71. The other types of scientific attitudes were ranked 3-11 in the following order; intellectual belief, perseverance, proactiveness, rationality, aversion to suspicion, 
humility, open-mindedness, honesty and suspended judgment showing that suspended judgement was the least attitude by the students in the study area with a mean score of 58.57. Comparing the mean score with the total maximum score obtainable, it could be concluded that most of the students possessed a high level of scientific attitude components except for honesty and openmindedness which respectively had a mean score of 4.50 and 5.23 from a maximum obtainable score of 10. The result is presented in Table 5 .

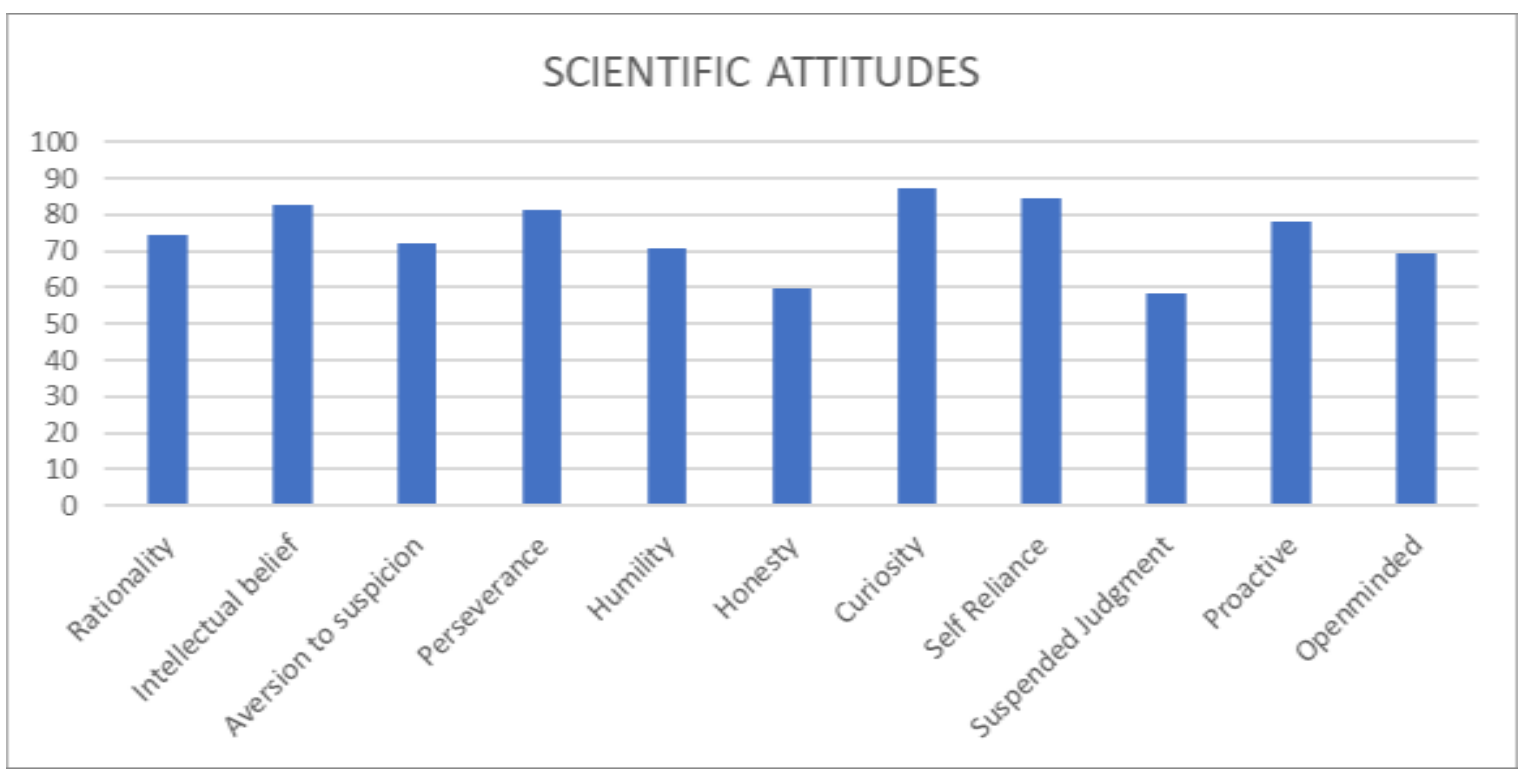

Figure 5: Bar Chart of Scientific Attitudes of Respondents

The relative strength of the three main components of scientific attitude was also determined as the attitudes were categorized into cognitive, affective and emotional component of scientific attitudes. To answer the question on the scientific attitude of the sampled respondents, Biology Scientific Attitude questionnaire was sectionalized into three components, which included Cognitive Components (Belief), Emotional Components (Feelings), and Attitudinal Components (Actions/Behavior). Results for each section as well as the combination of the sections are presented below. The cognitive components consist of rationality, intellectual belief, aversion to suspicion; the emotional components consist of perseverance, humility, honesty while the affective components consist of curiosity, self-reliance, suspended judgments, honesty, open mindedness, proactiveness. The results were presented below. 
Table 5: Descriptive Analysis of Components of Scientific Attitude of Respondents

\begin{tabular}{|c|c|c|c|c|c|c|c|c|c|}
\hline Attitude & $\begin{array}{l}\text { Max. } \\
\text { Score }\end{array}$ & Min. & Max. & Mean. & $\begin{array}{l}\text { Stand. } \\
\text { Dev. }\end{array}$ & $\begin{array}{l}\text { Adjusted } \\
\text { Mean }\end{array}$ & Rank & Skewness & $\begin{array}{r}\text { Std. Error } \\
\text { of } \\
\text { Skewness }\end{array}$ \\
\hline Cognitive & 28.00 & 10.00 & 28.00 & 20.02 & 3.09 & 75.79 & 2 & -0.22 & 0.109 \\
\hline Emotional & 28.00 & 9.00 & 28.00 & 19.05 & 3.29 & 72.00 & 3 & 0.28 & 0.109 \\
\hline Affective & 48.00 & 12.00 & 48.00 & 36.67 & 5.53 & 80.98 & 1 & -1.13 & 0.110 \\
\hline Cumulative & & 47.00 & 100.00 & 75.75 & 8.14 & & & -0.22 & 0.110 \\
\hline
\end{tabular}

Attitude

Table 5 above shows that the affective component of the scientific attitude was the most prominent among the students with an adjusted mean score of 80.98 . This was then followed by the cognitive component with an adjusted mean score of 75.79 and then the emotional component with an adjusted mean score of 72.00. A comparison of the mean score to the overall total possible score for each component indicate that the respondents possessed a moderate level of adequacy of cognitive, emotional and attitudinal scientific attitude as the mean scores were high relative to the maximum possible score. These components were categorized into high, moderate, and low.

Table 6: Percentage Analysis of Scientific Attitude of the respondents

\begin{tabular}{clll}
\hline Skills & Frequency & Percentage (\%) & Decision \\
\hline Cognitive Component & & & \\
Low & 96 & 19.3 & Moderate \\
Moderate & 288 & 57.7 & \\
High & 115 & 23.0 &
\end{tabular}

Emotional Component

$\begin{array}{lll}\text { Low } & 114 & 22.8\end{array}$

Moderate

269

53.9

Moderate
High
116
23.3 
Process skills application and scientific attitudes of Biology students in colleges of education in southwestern Nigeria.

Attitudinal Component

\begin{tabular}{llll} 
Low & 44 & 8.8 & \\
\multicolumn{1}{c}{ Moderate } & 404 & 81.0 & Moderate \\
High & 51 & 10.2 & \\
Attitude & & & \\
& 29 & 5.8 & Moderate \\
& 423 & $\mathbf{8 4 . 8}$ & \\
& $\mathbf{4 7}$ & $\mathbf{9 . 4}$ &
\end{tabular}

For the cognitive component, it was revealed that most of the respondents $(57.7 \%)$ demonstrated a moderate level of cognitive components, while $23.4 \%$ demonstrated a high level of cognitive components. Only 19.2\% demonstrated a low level of cognitive components. The table also revealed that $53.9 \%$ possessed a moderate level of emotional components, while only $23.2 \%$ and $22.8 \%$ demonstrated high and low levels of emotional components respectively. It was also observed from the table that most of the respondents $(81.0 \%)$ demonstrated a moderate level of attitudinal components of scientific attitude, while only $10.2 \%$ and $8.8 \%$ demonstrated high and low levels of attitudinal components respectively.

Table 6 showed the level of general attitudinal components exhibited by the respondents. From the table, the majority $(84.8 \%)$ demonstrated a moderate level of general attitudinal components, while only $9.4 \%$ and $5.8 \%$ demonstrated high and low levels of general attitudinal components respectively. It could then be concluded that there exists a moderate level of adequacy of cognitive scientific attitude, emotional scientific attitude and affective scientific attitude among respondents in the study area likewise a moderate level of overall scientific attitude. 


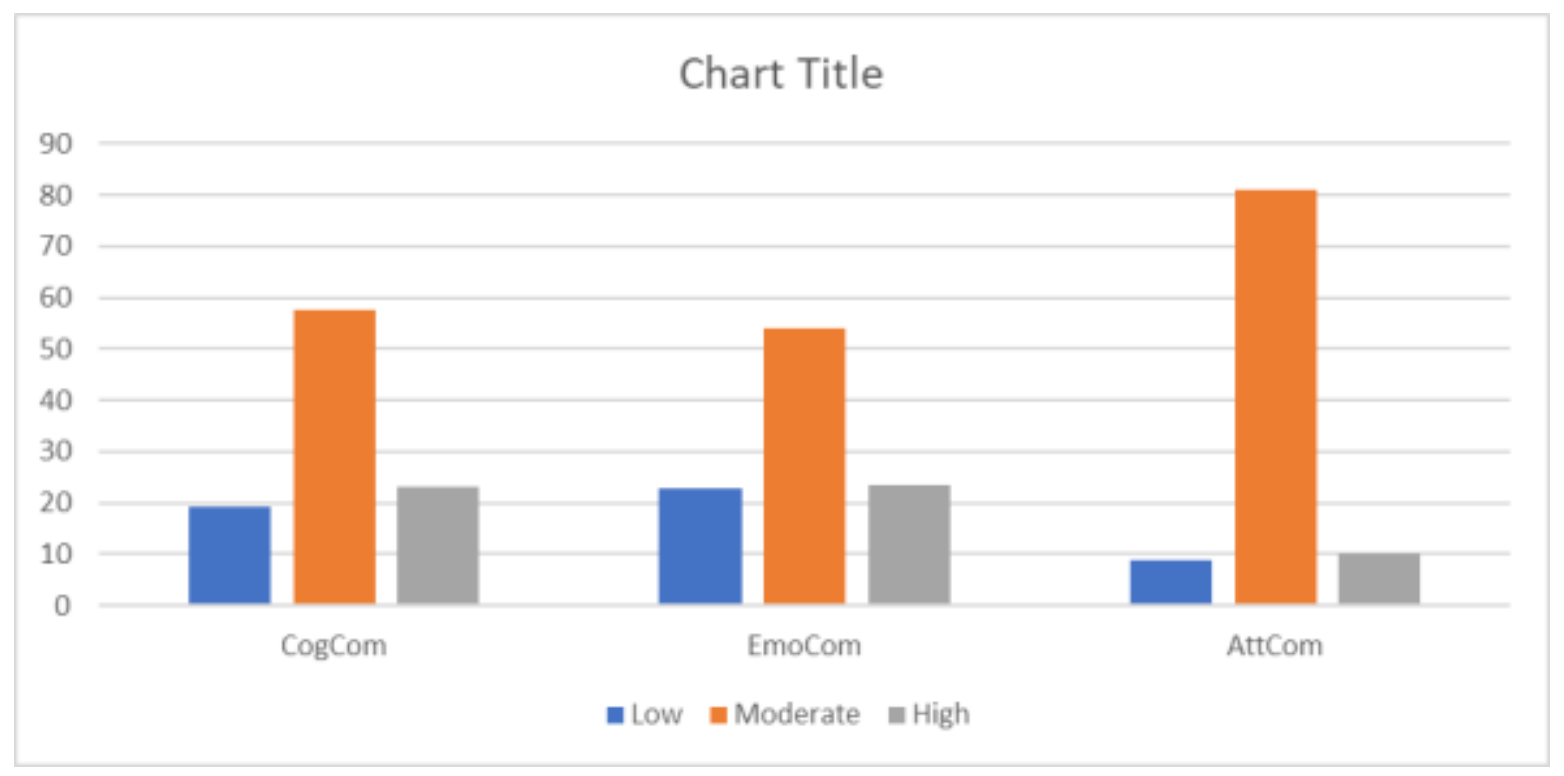

Figure 4.10.: Bar Chart on Levels of Scientific Attitude Components of Respondents

\section{Hypothesis One}

- There is no significant relationship between process skills application and scientific attitude of Biology students in colleges of education in Southwestern Nigeria.

To test this research hypothesis, bivariate Pearson product moment correlation was used first to determine the relationship between each of the components of the variables before the total variables were correlated. Cohen (1992) was then used to judge the strength of correlation among the variables. The result is presented in Table 7

Table 7: Correlation of Component of Process Skills Application, Higher Order Thinking Skills, Scientific Attitude and Creativity among Colleges of Education in Southwestern Nigeria

\section{Correlations}

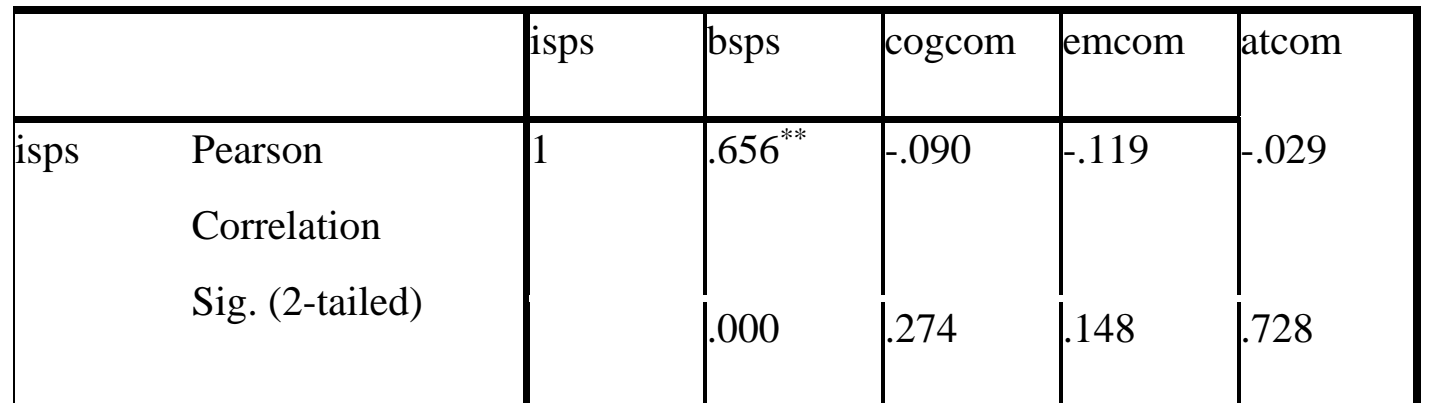


Process skills application and scientific attitudes of Biology students in colleges of education in southwestern Nigeria.

\begin{tabular}{|c|c|c|c|c|c|c|}
\hline & $\mathrm{N}$ & 149 & 149 & 149 & 149 & 143 \\
\hline bsps & $\begin{array}{l}\text { Pearson } \\
\text { Correlation } \\
\text { Sig. (2-tailed) } \\
\text { N }\end{array}$ & $\begin{array}{l}.656^{* *} \\
.000 \\
149\end{array}$ & $\left.\right|_{150}$ & ${ }_{150}^{.037}$ & $\begin{array}{l}.061 \\
.456 \\
150\end{array}$ & $\begin{array}{l}. .001 \\
.992 \\
144\end{array}$ \\
\hline cogcom & $\begin{array}{l}\text { Pearson } \\
\text { Correlation } \\
\text { Sig. (2-tailed) } \\
\text { N }\end{array}$ & $\begin{array}{l}-.090 \\
274 \\
149\end{array}$ & $\begin{array}{l}.037 \\
.653 \\
150\end{array}$ & $\left.\right|_{150}$ & $\begin{array}{l}.131 \\
.110 \\
150\end{array}$ & $\begin{array}{l}.053 \\
.530 \\
144\end{array}$ \\
\hline emcom & $\begin{array}{l}\text { Pearson } \\
\text { Correlation } \\
\text { Sig. (2-tailed) } \\
\text { N }\end{array}$ & $\begin{array}{l}-.119 \\
148 \\
149\end{array}$ & $\underbrace{.061}_{150}$ & $\begin{array}{l}.131 \\
.110 \\
150\end{array}$ & $\left.\right|_{150}$ & $\left.\right|_{144} ^{127}$ \\
\hline atcom & $\begin{array}{l}\text { Pearson } \\
\text { Correlation } \\
\text { Sig. (2-tailed) } \\
\text { N }\end{array}$ & $\begin{array}{l}-.029 \\
.728 \\
143\end{array}$ & $\begin{array}{l}-.001 \\
.992 \\
144\end{array}$ & $\int_{144}^{530}$ & $\begin{array}{l}.127 \\
.130 \\
144\end{array}$ & $\left.\right|_{144} ^{1}$ \\
\hline
\end{tabular}

**. Correlation is significant at the 0.01 level (2-tailed).

On comparison of each of the components of process skills application and scientific attitude. The study revealed that there existed a significant relationship between basic process skills and integrated process skills $(\mathrm{r}=0.656, \mathrm{p}<0.05)$ and the relationship is strong and positive. There was however no significant relationship between basic process skills application and all the components of scientific attitude in the study area $(\mathrm{p}>0.05)$.

There was however no significant relationship between the cognitive components of attitude and all other components of process skill application among Biology education students in colleges 
of education in southwestern Nigeria. There was also no significant relationship among the components of scientific attitude.

Table 8: Correlation Table of Overall PSA, HOTS, SC and SA in Colleges of Education in Southwestern Nigeria

\section{Correlations}

\begin{tabular}{|c|c|c|c|}
\hline & & PSA & $\mathrm{SA}$ \\
\hline PSA & $\begin{array}{l}\text { Pearson } \\
\text { Correlation }\end{array}$ & 1 & -.094 \\
\hline & Sig. (2-tailed) & & .260 \\
\hline & $\mathrm{N}$ & 150 & 144 \\
\hline $\mathrm{SA}$ & $\begin{array}{l}\text { Pearson } \\
\text { Correlation }\end{array}$ & -.094 & 1 \\
\hline & Sig. (2-tailed) & .260 & \\
\hline & $\mathrm{N}$ & 144 & 144 \\
\hline
\end{tabular}

**SA: Scientific Attitude

Table 8 revealed that there was no significant relationship between process skill application and Scientific attitude of the respondents in the study area as the relationship was both weak and negative $(r=-0.09, \mathrm{p}>0.05)$. It could be concluded that no significant relationship exists between process skills application and scientific attitude of respondents in the study area.

\section{Discussion of the Study}

The study reveals that there was a moderate level of application of basic and integrated process skills application among respondents in the study area. The findings of this study were in line with the research carried out by Segumpa (n.d.) which concluded that students possessed an average level of process skills as well as an average level of competency of basic process skills among the sampled respondents in his study. The implication of Segumpa's study is that these respondents might also be able to apply the skills. 
However, the findings of the current study differ from Segumpa finding in the area of integrated skills, as the Segumpa's revealed a poor level of competency of the skill. Other areas where the findings of our study agree with that of Segumpa are in the individual components of the process skill application. The findings agree with Segumpa's in revealing an average level of competency for observation skills, measuring skills, and classification. Our study revealed an average level of interpreting variables, predicting variables, and inferencing and controlling variables disagreeing with Segumpa's findings of a low level of application of these skills among the respondents. The findings were also consistent with those of Sunyono (2018) that revealed an average level of process skills and an average level of observation and classification skills given that the lowest rating obtained was on predicting and interpreting. Our study diverged from Sunyono's in that communication skills which was the least applied skills by the respondents in his was the most applied process skills by respondents in colleges of education in Southwestern Nigeria. The findings of the study do not agree with that of Azizah et. al (2018) whose work revealed a high level of process skills application when instruments for measuring process skills were assessed. It is essential to note from the study that prediction and inferencing skills that are low are interconnected. This will account for the reason why the skills for formulating models will be low as these two skills, of prediction and inference, are needed to formulate models. We could then posit that that if the skill of prediction and inferencing are improved upon, students will be able to effectively formulate models in science.

The study reveals a moderate level of adequacy of scientific attitude among respondents in the study area. It reveals that curiosity and self-reliance are the attitude most possessed among respondents while honesty and suspended judgement are the least possessed scientific attitude among respondents in the study area. This result is partially in line with the work of Olatoun (2017) that revealed a high level of scientific attitude among selected graduate employees in Nigeria. As honesty was the highest in Olatoun's study, this study is at variance with hers as honesty was the lowest in our study. The semantics used and mannerism of constructing the items might be responsible for this. The result was partially in line with the work of Pitafi and Farooq (2012) whose study revealed that curiosity was the highest level of scientific attitude possessed by the students while willingness to suspend judgement was the lowest level of attitude demonstrated by the students. On this, findings of our study agree with Pitafi and Farooq (2012). The result of the 
current study also partially agreed with that of Lacap (2015) where a moderate level of attitude was seen for rationality and suspended judgement.

Our study reveals that there was no significant relationship between process skills application and the scientific attitude of respondents in the study area. It also shows a significant positive relationship between basic and integrated process skills. The findings did not agree with those of Giwa, Libata and Wakkala (2018) that revealed significant relationship between science process skills and attitudes of students in Nigeria. However, the study was carried out on Physics and subject variation could be a factor in the difference seen in the results of the study.

Process skill application did not affect scientific attitude of respondents in the study area, it could be said that there are other factors that will help to improve scientific attitude in the study area. Many of the literatures reviewed were also in other fields of science like Chemistry, Physics and mathematics. Also, factors relating to the application of process skills can be examined to determine why there was no relationship between the application of process skills and scientific attitude. It could mean that students do not carry out practical activities in the right way using standard best practices. If this is not done, the influence of the application of process skills on scientific attitude could be defeated. Another factor could also be because practical classes in colleges of education and even secondary schools in Nigeria are carried out in large groups where only one student does the activity and others look on or assist. It is only on rare occasions that each student carries out all the expected activities for a particular experiment. This will definitely have an effect on the holistic understanding of scientific concept and on improving the scientific attitude of the student. To improve process skills application, each individual student should carry out all the expected activities as each component has a part to play in improving the overall acquisition of skills, knowledge and attitude of the students.

\section{Conclusion}

The conclusion of the study is that there was a moderate level of basic and integrated process skills application among respondents as well as a moderate level of application of overall process skills among the respondents in the study area. There was a moderate level of scientific attitude among respondents in the study area. The study concludes that the Biology students in the selected colleges of education had a moderate level of adequacy for the cognitive, emotional and attitudinal components of scientific attitude in the study area. 
On the relationship among the variables of the study, the study findings reveals that there was no significant relationship between overall process skills application and scientific attitude among respondents in the study area, though the structure of practical classes could be responsible for the lack of relationship as it is expected that process skill will help to improve general understanding of various component of science of the students.

\section{Recommendations}

Based on the findings from our study we recommend that practical activities be emphasized, and the appropriate practical procedures be followed in colleges of education in southwestern Nigeria. This will help to develop the process skills application of pre-service teachers in those colleges of education. In developing the science process skills in the right way, students will also simultaneously learn appropriate scientific attitude of curiosity, honesty and open mindedness required of Biology teachers. Emphasis should also be laid on the development of integrated process skills by allowing students do more of practical than the alternative to practical right from secondary schools. It is also important that while teaching students in the classroom, teachers and instructors should watch out for how well students imbibe right attitudes in science as this could also be evaluated in the students. Emphasis should be placed on making resources and facilities available so that practical classes will not be muddled up and every student are able to carry out activities individually and appropriately.

\section{References}

Ango, M. L. (2002). Mastery of Science Process Skills and Their Effective Use in the Teaching of Science: An Educology of Science Education in the Nigerian Context. International Journal of Educology, 16(1), 11-30.

Arokoyu, A. A. \& Nna, P. J. (2012). Creativity and Process Sills for Self Reliance using

Demonstration Approach of Teaching Chemistry. ARPN Journal of Science and Technology. 2(11). 1029-1033

Azizah, K. N. Ibrahim, M., Widodo, W. (2018). Process Skill Assessment Instrument: Innovation to measure student's learning result holistically. Journal of Physics: Conference Series .947. doi :10.1088/1742-6596/947/1/012026 
Babajide, V. F. T. (2015). Science education in Nigeria: The journey so far International Journal of Innovative Research in Education, Technology and Social Strategies, 1(1), 53-69.

Cheng, C. (2009). Dialectical Thinking and Coping Flexibility: A Multimethod Approach. Journal of Personality. 77(2). 471-494

Danmole, B. T. (2012). Biology Teachers' View on Practical Work in Senior Secondary Schools of Southwestern Nigeria. Pakistan Journal of Social Science, 9(2), 69-75

Ekon, E. E. \&Eni, E. I. (2015). Gender acquisition of science process skills among Junior secondary school students in Calabar Municipality: Implication for Implementation of Universal Basic Education Objectives. Global Journal of Educational Research, 14, 93-99.

Federal Republic of Nigeria (2004). National policy on education. Abuja: Federal Ministry of Education.

Giwa, A.A. , Kamba, A. H. \& Wakkala, G. T. (2018). The relationship between science process skills and student attitude towards Physics in senior secondary schools in Aleiro Metropolis. African Educational research Journal. 6(3), 107-113

Gokul, R. R. \& Mallinga T. (2015). A study of the Scientific Attitudes among Preservice Teachers. Research Journal for Receent Science. Vol. 4, 196-198

Idiege, K. J. , Nja, C. O. \& Ugwu, A. W. (2017). Development of Science Process Skills among Nigerian Secondary School Students and Pupils: An Opinion. International Journal of Chemistry Education. 1(2).13-21 Nsukka.

Lacap, Marjorie P. (2015). The Scientific Attitudes of Students Major in Science in the New Teacher Education Curriculum. Asia Pacific Journal of Multidisciplinary Research, Vol. 3, (No. 5), 7-15.

Lloyd J. M. \& Kathleen M. (2012). Virgnia's Water Resources. How can we understand our water Resources? Longwood University.

National Universities Commission (2018). National Universities Commission benchmark for Academic Standard. Lagos: NUC

Nwagbo, C. \& Uzoamaka,, C.C. (2011). Effects of Biology Practical Activities on Process Skills Acquisition. Journal of Science Teachers Association of Nigeria 4(1). 58 
Nwosu, A.A. (2007). Acquisition of science process skills by students' different cognitive levels. The effects of teacher sensitization programme. Review of Education, 13, 155-165.

Olatoun, O. R. (2017). Scientific Attitude Development of Some graduate Employees in Some Selected Industries. International Journal of Management and Applied Science. 3(1), 134139.

Omoifo, CN. (2012). Dance of the Limits, Reversing the Trends in Science Education in Nigeria, Inaugural Lecture University of Benin, Benin City.

Pitafi, A.I And Farooq, M.(2012). Measurement of Scientific Attitude Of Secondary School Students In Pakistan. Academic. Research International, 2(2), 379-392.

Segumpa, R. D. (N.D.). Bruenian Education Students Science Process Skills. : Implication to Curriculum and Management. Journal of Science and Mathematics Education in S.E. Asia, 24(2), 21-39.

Sirhan, G. (2007). "Learning difficulties in chemistry: An overview." Journal of Turkish science education, 4(2), 2.

Sunyono, S. (2018). Science Process Skills Characteristics of Junior High School Students in Lampung. European Scientific Journal. 14(4) pp. 32-45

Utsa E. \& Akkanat, C. (2014). Investigating Scientific Creativity Level of Seventh Grade Students. Available online at www.sciencedirect.com. Published by Elsevier Ltd.

(http://creativecommons.org/licenses/by-nc-nd/4.0/).WCES2014.doi: 10.1016/j.sbspro.2015.04.643

WAEC (2014). The West African Examination Council Chief Examiners' Report. West African Senior School Certificate Examination (WASSCE) May/June, 2014 